\title{
Information safety of Ukraine: Integral assessment and taxonomic analysis
}

\section{Alina Yakymchuk ${ }^{a}$, Nazariy Popadynets ${ }^{b^{*}}$, Oleh Yakymchuk ${ }^{c}$, Taras Vasyltsiv $^{b}$, Inna Ir- tyshcheva $^{d}$, Rostyslav Bilyk ${ }^{\mathrm{e}}$, Yurii Khomosh ${ }^{\mathrm{f}}$, Oryslava Hrafska ${ }^{\mathrm{g}}$, Valentyna Yakubiv ${ }^{\mathrm{h}}$ and Oleksandr Irtyshchev ${ }^{d}$}

${ }^{a}$ National University of Water and Environmental Engineering, Ukraine

${ }^{b}$ State Institution "Institute of Regional Research named after M. I. Dolishniy of the NAS of Ukraine”, Ukraine

"LLC "Rivne Oblast Energy Supply Company", Ukraine

${ }^{d}$ Admiral Makarov National University of Shipbuilding, Ukraine

${ }^{e}$ Yuriy Fedkovych Chernivtsi National University, Ukraine

${ }^{f}$ Drohobych Professional College of Oil and Gas, Ukraine

${ }^{g} I$. Boberskyi Lviv State University of Physical Culture, Ukraine

${ }^{h}$ Vasyl Stefanyk Precarpathian National University, Ukraine

\section{H R O N I C L E \\ A B S T R A C T}

Article history:

Received: September 20, 2020

Received in revised format:

January 15, 2021

Accepted: January 16, 2021

Available online: January 16, 2021

Keywords:

Informational Security

Taxonomic Analysis

Modeling

Integral Index

Ukrainian Regions

\begin{abstract}
The global process of society information has covered almost all countries of the world and is currently the core of scientific, technical and socio-economic development. The effectiveness of the power exercise in any state depends on its information support. Indeed, without information, successful political structure, the development of mass political consciousness as well as the interaction of the subject and the object of government are impossible. That is why this research aims to improve the methodics of evaluation of informational security through theoretical-methodological substantiation, forming and calculation of integral indexes of its competitiveness of a country. Global economic crisis had consequences for almost every country and cannot be ignored by any conditions, that is why the methodic of informational security calculations should be adapted to modern economic conditions. Cardinal changes in political, economic and social conditions in Ukraine causes inaccessibility of approaches to information security level calculations and particularly in the national security system. In modern scientific schools the questions of effective informational security have not been sufficiently studied. The aim of this article is to analyze active methods of state informational safety level calculations in order to adapt their indexes to actual global circumstances in Ukraine and in the world. Integral informational security have been composed of such components (indicators): income of the broadband Internet access market, dynamics of broadband Internet subscribers (connections), penetration rate of fixed broadband access (number of subscribers per 100 people), dynamics of Internet penetration (percentage of Internet users to the total population of the country), Network Readiness Index of the country, ICT Development Index of the state, Global Innovation Index, capital investments in intangible assets of Ukraine (that is, in software and databases). Every component of informational safety has factors of relevance and indispensability of reinforcement of national competitiveness on security foundations are substantiated. A taxonomic indicator is used to measure the level of informational safety. The paper proves that each of the components of the state informational security has almost equal input in forming its integral index.
\end{abstract}

\section{Introduction}

In modern society, information has become one of the most important national strategic resources, and the problem of state information security has acquired particular importance in the context of the widespread use of automated information systems. Information security means such a state of information protection resources of the individual, society and the state, 
ensures the implementation and progressive development of vital interests for them. The most important elements of a modern information security system are: accessibility (the ability to receive the necessary information service within a certain time), integrity (relevance and consistency of information, its protection from destruction and unauthorized modification), confidentiality (protection from unauthorized access). The main objective of information security is to safeguard the confidentiality, integrity and availability aspects of information systems and data from any vulnerabilities and threats, especially when such threats and vulnerabilities are on the rise.

Within the framework of information support for national security, protection of personal information, the fight against cybercrime is a matter of particular relevance for European countries, which is due to the high level of computer equipment in various spheres of society. In the countries of the European Union, there are a number of regulations governing the fight against computer crime. In particular, these are Articles 29, 34 of the Treaty establishing the European Union, Directive 95/46/EC of the European Parliament and of the Council of 24 October 1995 "On the protection of individuals with regard to the processing of personal data and on the free movement of such data"; Regulation No 45/2001 of the European Parliament and of the Council of 18 December 2000 "On the protection of individuals with regard to the processing of personal data by the Community institutions and bodies and on the free movement of such data", Council Resolution of 17 January 1995 "On the lawful interception of telecommunications" (96/C 329/01) (European Commission, 2019). The Common position of the member states of the European Union on the content of the "information security" concept was expressed by the representative of Sweden during the discussion of international information security at the 56th session of the UN General Assembly, according to which information and network security means the protection of personal information about senders and recipients, protection of information from unauthorized changes, protection from unauthorized access to information and creation of a reliable source of supply of equipment, services and information. All this requires from Ukraine, which has just embarked on the path of European integration development, a detailed research of European information security instruments in order to increase its level in the globalized world.

In modern conditions of development, it is information security, as one of the characteristics of sustainable development, that acts as the basic value of the state. At the same time, the value orientations based on ideas about information security in different countries of the world, public groups and individuals often do not coincide. It is in this that the influence of the state finds its direct expression, with the help of a system of methods and effective regulatory tools, forms common values in the field of information security.

Information is now the most valuable global resource, since the economic potential of a society is determined primarily by the volume of its information resources and the level of development of information infrastructure. Information itself is a dynamic phenomenon, the constant changes of which lead to the transformation of its quality, an increase in the number of information sources and consumers. Consequently, the modern information society is under the constant threat of receiving inaccurate and sometimes harmful information, its untimely receipt, industrial espionage, computer crime, etc.

Therefore, the information sphere in Ukraine should become a determining factor in achieving geopolitical advantages. In addition, the component of "information support" in hybrid wars is extremely important, if not decisive. At the same time, information wars intensified at the end of 2014, sharply reduced the level of confidence of Ukrainian citizens in the media. For the first time in the entire period of the monitoring "Ukrainian Society" indicators of distrust to the media in Ukraine turned out to be higher than the indicators of trust. Now the media are trusted (in general or mainly) by 25 percent and not trusted by 45 percent of the adult population, whereas a year ago - 37 and 29 percent, respectively (excluding residents of Crimea) (Veche, 2015).

UN activities are of great importance for the information society development. Even at the initial stage of the Organization's activities, the General Assembly proclaimed freedom of the press, as well as the right to information in the Universal Declaration of Human Rights. One of the main factors at today's stage is transforming the world is globalization, which is based on the revolution in information technology. It is obvious that the large-scale support of the peoples of the world, which the UN provides, is impossible without information support; everything is becoming an increasingly important aspect of improving the effectiveness of peacekeeping operations. In recent years, the role of information has grown significantly: it is a driving force for promoting mutual understanding between cultures and increasing people's participation in decision-making that affects their lives.

\section{Literature review}

Currently there is a considerable and diversified basis of methodical approaches and methods of evaluation of informational safety and its components. The interpretation of the term "information security" is of scientific and practical interest. So, for instance, scientists Avramenko and Haseskyi (2012) define information security as a protection state of the vital interests of the individual, society and the state, excludes the possibility of causing harm to them due to incompleteness, untimely and unreliable information, for the negative consequences of the functioning of information technologies or as a result of the dissemination of legally prohibited or restricted information for dissemination, while Litvinenko (2003) defines information security as the state of security of the information space, ensuring the formation and development of this space in the interests of the individual, society and the state. A similar understanding of the content of information security concept was put in by Shulga (2015) who emphasizes the importance of the political elite role capable of resisting information impact. In his opinion, 
information security is the state of the information environment of society and the political elite, which ensures its formation and development in the interests of the country's leadership, citizens and society.

Petrik and Galamba (2006) did not agree as he has an opposite opinion in comparison with the scientists mentioned above. By information security, he understands the state of information security, ensures the vital interests of a person. Within the framework of this direction, there is a definition of information security as a state, development trend, conditions of life of society, its structures, institutions and institutions, under which the preservation of their quality with objective conditioned functions is ensured. Supporters of this position consider information security as a state characterized by the absence of danger, that is, factors and conditions that threaten directly an individual, society, and the state from the side of the information and communication environment (Stehnei, 2021).

There are a number of approaches for assessing information security in the scientific literature. However, many of the suggested approaches have some weaknesses related to omission of the weight of researched indicators in forming an integral index or to taking into account only the multivariate average values. Moreover, permanent technological dynamism and global impact of leading technologies on the development of national security stipulate the need for occasional adjustment of scientific methodics by the change of the list of estimated indicators, increasing reliability of data sources, providing complete primary information and improvement of an algorithm of outcome indicator's calculation. For an adequate assessment of the integral indicator of information security, this study used taxonomic analysis.

In general, taxonomic analysis is widely used in the research of various economic phenomena and processes. So, the exact method of its implementation is described in the works of Edsand (2019), Ilyash, et al. (2018), Pliuta (1980) and Ivanova et al. who proposed a comparative multidimensional analysis in economic research. The method of taxonomic analysis was applied in the works of Riepina (2011) in the analysis of the formation and use of the enterprises assets effectiveness; O. Pavlova et al. (2021) in the analysis of the cyclical development of the socio-economic system; Stroyko et al. (2013), Yakubiv (2015), Was et al. (2020), Andrusiv et al. (2020) in the analysis of sustainable development of the agricultural sector economy of Ukraine; Popadynets and Maksymiv (2016), Wisz et al. (2018) and Vasyltsiv et al. (2020) in the competitiveness of industrial products research. However, the information security research and the construction of its integral indicator in the structure of national security requires a deeper study. All this became the object of scientific research and formed the range of scientific interests of this work.

Taxonomy is the science of rules for systematization and classification. At first, this concept was used only to define science, the classification of plants and animals. At the moment, representatives of economic and managerial scientific circles began to use taxonomy more and more often (Pryshchepa et al., 2020). It is known that Hellwig (1981) was the first to use a special research technique for aggregating features. He proposed a taxonomic indicator, which is a synthetic value formed from all the characteristics that characterize the phenomenon under research.

We support the idea of scientists, information about the properties of the distribution of a multidimensional random variable belonging to the concept of a distribution spectrum can be obtained using taxonomic methods. These methods make it possible to split a set of data (object of taxonomic research) into subsets that do not overlap. That is why we use a modern taxonomic approach to assess the level of information security.

When constructing a taxonomic indicator, a data matrix or one composed of standardized implementations of features is used. Standardization allows you to get rid of units of measurement, both natural and monetary. At the same time, the variance is equalized (each variance becomes equal to one), as well as the values of the features (all arithmetic means are equal to zero), which is undesirable, since because of this, each feature in the same way affects the analysis results. Therefore, in some cases, a hierarchy of features is established using the corresponding coefficients of the hierarchy, differential features according to their importance for this study. Coefficients are determined by analysis or by appropriate methods (Matthews, 2001).

In the context of the current military-political situation, which has now developed in Ukraine, economic instability caused by the pandemic of the COVID-19 virus, it is considered appropriate to adapt this methodology specifically to identifying weaknesses in information security in particular and in the national security system as a whole, taking place in connection with the military events in Ukraine. Each component of information security should take into account the above factors, which in one way or another ultimately adjust the integral indicator. Therefore, in some cases, a hierarchy of features is established using the corresponding coefficients of the hierarchy, differential features according to their importance for this study. Coefficients are identified based on analysis or using appropriate methods (Kozhushko, 2014).

\section{Materials and Methods}

The authors' methodics stipulates calculation of integral index of informational security (on the example of Ukraine). The methodics consists of seven stages:

1) forming of indicators of information security across Ukraine in the defined time period (12 years - from 2008 till 2019) by stimulant indicators: income of the broadband Internet access market, dynamics of broadband Internet subscribers (connections), penetration rate of fixed broadband access (number of subscribers per 100 people), dynamics of Internet penetration (percentage of Internet users to the total population of the country). The selected system of information security indicators of Ukraine is in the plane of completeness, confidentiality and integrity of information, while ensuring its availability with the 
authorization of the dissemination of information. All indicators are stimulants, since their growth ensures an increase in the level of information security in Ukraine;

2) normalization of indicators;

3) determining of indicators' weight in the groups;

4) calculation of weighted indices of the groups of indicators;

5) weight determining of indicators' each group;

6) calculation of integral indices by competitiveness groups;

7) construction of integral index.

To measure the level of information security, a taxonomic indicator was used in this research. A taxonomic indicator acts as a synthetic value that takes into account the influence of the values of a set of indicators on the development level of the object under study, while the indicators are ordered by distance to some artificially constructed point called the development standard (Day, 1955).

The taxonomic analysis is based on the formation of a matrix of observations $\mathrm{X}$ of dimensions $m \times n$ ( $m$ is the number of periods, $n$ is the number of features), which contains an exhaustive description of the object under study:

$$
X=\left(\begin{array}{ccccc}
x_{11} & \ldots & x_{1 j} & \ldots & x_{1 n} \\
\ldots & \ldots & \ldots & \ldots & \ldots \\
x_{i 1} & \ldots & x_{i j} & \ldots & x_{i n} \\
\ldots & \ldots & \ldots & \ldots & \ldots \\
x_{m 1} & \ldots & x_{m j} & \ldots & x_{m n}
\end{array}\right)
$$

where $i$ - serial number of the period $(\mathrm{i}=1, \ldots, \mathrm{m}, m=12) ; j$ - indicator characterizing the state of the object under study $(\mathrm{j}=1, \ldots$, n, $n=8) ; x_{i j}$ - value of the $j$-th indicator for the $i$-th period.

We assess the information security level of Ukraine in the national security system by analyzing the existing system of indicators, according to the main areas of information security (Table 1).

At the same time, the distance between the standardized values of the information security indicators of Ukraine for individual years and the reference vector was calculated using the formula:

$$
C_{i 0}=\sqrt{\sum_{j=1}^{n}\left(z_{i j}-z_{0 j}\right)^{2}}
$$

where $C_{i 0}$ - distance between the standardized values of information security indicators of Ukraine and the ideal vector;

$Z_{\mathrm{i} j}-$ standardized value $x_{i j}$ of the information security indicator;

$z_{0 j}$ - standardized value of the $i$-th indicator in the ideal;

$i$ - serial number of the research year $(i=\overline{1,12})$;

$j-$ serial number of the indicator $(\mathrm{j}=1.8)$.

The average distance between the standardized values of the indicators and the ideal vector is calculated by the formula:

$$
\overline{C_{0}}=\sum_{i=1}^{m} C_{i 0}
$$

While the distance between the standardized values of the information security indicators and the ideal vector is calculated for each year separately, the value of the average distance between the standardized values of the indicators and the ideal vector will be one for 12 years old. The total distance between the indicators and the ideal is calculated by the formula: 


$$
C_{0}=\bar{C}_{0}+2 \sqrt{\frac{1}{m} \sum_{i=1}^{m}\left(C_{i 0}-\overline{C_{0}}\right)^{2}}
$$

The obtained distance serves as the basis for calculating the indicator of the information security level of Ukraine.

The deviation of the indicators of the $i$-th year from the ideal is calculated by the formula:

$$
d_{i}=\frac{C_{i 0}}{C_{0}}
$$

and the indicator of the information security level is found by the following formula:

$$
K_{i}=1-d_{i}
$$

The construction of an indicator of the use efficiency consists in certain elements of the observation matrix and their standardization, after which the differentiation of features is carried out. In this case, all variables should be divided into stimulants and de-stimulants. The basis of such a distribution is characterized by the influence of each of the indicators on the development level of the studied object. Signs that have a positive effect (stimulation) on the general level of development of an object are called stimulants, signs that have a negative effect are called de-stimulants. This separation is the basis for building a vector - an ideal. The elements of this vector have coordinates Xoi and are formed from the values of the indicators according to the formula:

$$
X_{o i}=\max x_{i j} \text { (stimulant), } X_{o i}=\min x_{i j} \text { (de-stimulant) }
$$

The next step in determining the indicator of the taxonomic level of information security is to determine the distances between individual observations (periods) and the ideal vector. Thus, the taxonomic indicator of the information security level of the state is constructed and synthetically characterizes changes in the values of features. Its most important property is that now we have to deal with one synthetic feature, it shows the direction and scale of changes in the processes described by a set of an arbitrary number of input features that characterize the state and the development level of the system.

\section{Results and discussion}

Based on the suggested methodics the average values of integral indices of provision of information security in Ukraine are identified. The value of the information security indicators of Ukraine for the studied period (2008-2019), are elements of the observation matrix, are given in Table 1. Based on the influence nature of indicators on the information security level in Ukraine, the authors of the article differentiated them into stimulants and de-stimulators, that is, those that have a positive effect on the integral indicator of information security and those that negatively affect it. Taking into account the different dimensions of indicators and the need to ensure their comparability, the authors of the research standardized the values of indicators according to the following formulas (7) and (8).

For stimulant indicators:

$$
z_{i j}=\frac{x_{i j}-\bar{x}_{j}}{\sigma_{j}}
$$

For de-stimulant indicators:

$$
z_{i j}=\frac{\bar{x}_{j}-x_{i j}}{\sigma_{j}}
$$

where $z_{i j}$ - standardized value of $x_{i j}$ indicator;

$\bar{x}_{j}$ - average value of the $j$-th indicator;

$\sigma_{j}-$ standard deviation of the $j$-th indicator.

The interpretation of this indicator is as follows: it takes high values at large values of stimulants and low values - at low values of stimulants. The closer the value of the coefficient $d_{i}$ to 1 , the higher development level of the economic potential management of trade enterprises as a system is considered. The authors carried out the standardization of information security indicators in Ukraine, as a result of which a matrix of $\mathrm{Z}$ standardized values was formed. 
Table 1

The main indicators that characterize the information security of Ukraine

\begin{tabular}{|c|c|c|c|c|c|c|c|c|c|}
\hline Year & 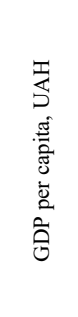 & 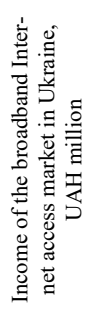 & 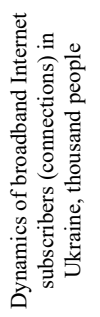 & 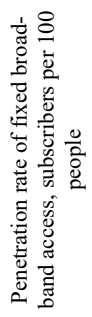 & 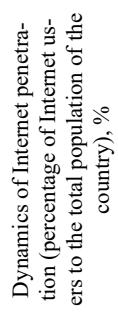 & 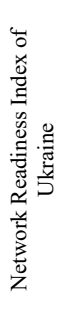 & 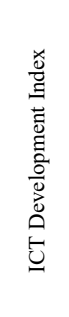 & 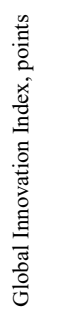 & 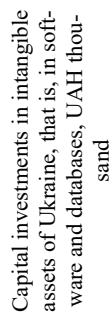 \\
\hline 2008 & 3500.2 & 3856 & 14.3 & 22 & 3.69 & 4.33 & 32.4 & 3250.3 & 3500.2 \\
\hline 2009 & 3900 & 3900 & 12 & 25 & 3.88 & 4.34 & 32.9 & 3100.6 & 3750.4 \\
\hline 2010 & 3900 & 5300 & 18 & 33 & 3.53 & 4.47 & 34.5 & 2802.4 & 3900 \\
\hline 2011 & 4000 & 6000 & 28 & 39 & 3.53 & 4.97 & 35 & 3254 & 4000 \\
\hline 2012 & 4150 & 5300 & 10 & 50 & 3.85 & 5.15 & 36.1 & 3409.1 & 4150 \\
\hline 2013 & 4223 & 3848 & 11.2 & 53 & 3.87 & 5.15 & 35.78 & 3207.3 & 4223 \\
\hline 2014 & 4503 & 3946 & 10.4 & 57 & 3.87 & 5.2 & 36.3 & 4908.4 & 4503 \\
\hline 2015 & 5222 & 4979 & 8.8 & 58 & 4 & 5.23 & 36.5 & 6315.5 & 5222 \\
\hline 2016 & 6055 & 5012 & 11.81 & 63 & 4.2 & 5.31 & 35.71 & 8196.4 & 6055 \\
\hline 2017 & 6000 & 5000 & 11.8 & 64 & 4.3 & 5.62 & 37.6 & 8200.1 & 6000 \\
\hline 2018 & 5319 & 5100 & 12.2 & 63 & 4.4 & 5.66 & 38.5 & 8100.7 & 5319 \\
\hline 2019 & 5400 & 4900 & 12.6 & 71 & 4.46 & 5.5 & 37.4 & 7767.2 & 5400 \\
\hline
\end{tabular}

Source: own research

$$
Z=\left(\begin{array}{cccccccccccc}
-1.31 & -1.03 & -0.86 & -0.75 & -0.58 & -0.50 & -0.19 & 0.62 & 1.56 & 1.50 & 0.73 & 0.82 \\
-1.28 & -1.22 & 0.76 & 1.75 & 0.76 & -1.30 & -1.16 & 0.31 & 0.35 & 0.34 & 0.48 & 0.20 \\
0.17 & -0.28 & 0.89 & 2.83 & -0.67 & -0.43 & -0.59 & -0.90 & -0.31 & -0.32 & -0.24 & -0.16 \\
-1.71 & -1.53 & -1.03 & -0.67 & 0.01 & 0.19 & 0.44 & 0.50 & 0.81 & 0.87 & 0.81 & 1.30 \\
-0.87 & -0.27 & -1.38 & -1.38 & -0.36 & -0.30 & -0.30 & 0.11 & 0.74 & 1.06 & 1.38 & 1.57 \\
-1.60 & -1.58 & -1.30 & -0.23 & 0.16 & 0.16 & 0.26 & 0.33 & 0.50 & 1.16 & 1.25 & 0.90 \\
-1.83 & -1.56 & -0.68 & -0.40 & 0.21 & 0.03 & 0.32 & 0.43 & -0.01 & 1.03 & 1.53 & 0.92 \\
-0.84 & -0.91 & -1.04 & -0.84 & -0.78 & -0.86 & -0.13 & 0.48 & 1.29 & 1.29 & 1.25 & 1.10
\end{array}\right)
$$

The formation of the ideal vector $P_{0}=\left(z_{01}, \ldots, z_{0 m}\right)$ was carried out by selecting from the columns of the matrix $\mathrm{Z}$ the maximum value for all indicators.

$P_{0}=(1.56,1.75,2.83,1.30,1.57,1.25,1.53,1.29)$

Considering the value of the ideal vector, additional indicators were calculated: the distance between observations and the ideal vector, the average and total distance of deviations from the ideal (Table 2). The obtained distance serves as the basis for calculating the indicator of the information security level of Ukraine.

Table 2

The results of the calculation of the taxonomic indicator of the level of Ukraine's economic security

\begin{tabular}{|c|c|c|c|c|c|}
\hline Year & $\begin{array}{l}\text { Distance between the } \\
\text { standardized values } \\
\text { and the ideal vector, } \\
C_{0 j}\end{array}$ & $\begin{array}{l}\text { Average distance be- } \\
\text { tween the standard- } \\
\text { ized values of the in- } \\
\text { dicators and the ideal } \\
\text { vector, } \overline{C_{0}}\end{array}$ & $\begin{array}{l}\text { Total distance be- } \\
\text { tween the indicators } \\
\text { and the ideal, } C_{0}\end{array}$ & $\begin{array}{l}\text { Deviation of indica- } \\
\text { tors of the } j \text {-th year } \\
\text { from the ideal, } d_{j}\end{array}$ & $\begin{array}{l}\text { Security level indica- } \\
\text { tor, } K_{j}\end{array}$ \\
\hline 2008 & 7.97 & 5.33 & 8.30 & 0.96 & 0.04 \\
\hline 2009 & 7.68 & 5.33 & 8.30 & 0.93 & 0.07 \\
\hline 2010 & 6.45 & 5.33 & 8.30 & 0.78 & 0.22 \\
\hline 2011 & 5.32 & 5.33 & 8.30 & 0.64 & 0.36 \\
\hline 2012 & 5.52 & 5.33 & 8.30 & 0.66 & 0.34 \\
\hline 2013 & 6.08 & 5.33 & 8.30 & 0.73 & 0.27 \\
\hline 2014 & 5.65 & 5.33 & 8.30 & 0.68 & 0.32 \\
\hline 2015 & 4.73 & 5.33 & 8.30 & 0.57 & 0.43 \\
\hline 2016 & 3.97 & 5.33 & 8.30 & 0.48 & 0.52 \\
\hline 2017 & 3.55 & 5.33 & 8.30 & 0.43 & 0.57 \\
\hline 2018 & 3.47 & 5.33 & 8.30 & 0.42 & 0.58 \\
\hline 2019 & 3.53 & 5.33 & 8.30 & 0.43 & 0.57 \\
\hline
\end{tabular}

Source: calculated by the official site of State Statistics Service of Ukraine, 2020

The taxonomic indicator of the information security level of Ukraine has been calculated for 2008-2019. Demonstrates a growing trend and dominance in the crisis state of information security in Ukraine. It acquired the least value in 2008 (0.04), and the largest - in 2018 (0.58). Ensuring this level became possible thanks to the growth of almost all indicators of information security, in all - the dynamics of Internet penetration (from $22 \%$ in 2008 to $71 \%$ in 2019), capital investments in intangible assets of Ukraine (from UAH 3250.3 thousand in 2008 to UAH 7767.2 thousand in 2019). 
Graphically shows the dynamics of changes in the indicator of the information security level of Ukraine (Fig. 1).

The growing dynamics of the indicator of the information security level indicates an increase in the degree of information technologies accessibility in Ukraine. However, the failure to achieve a safe state of information security in Ukraine during 2008-2019 emphasizes the need to ensure adequate security of information.

Thus, the use of taxonomic analysis made it possible to conduct a comprehensive assessment of important components of Ukraine's national security, calculate the integral level of security, identify negative development trends and potential threats.

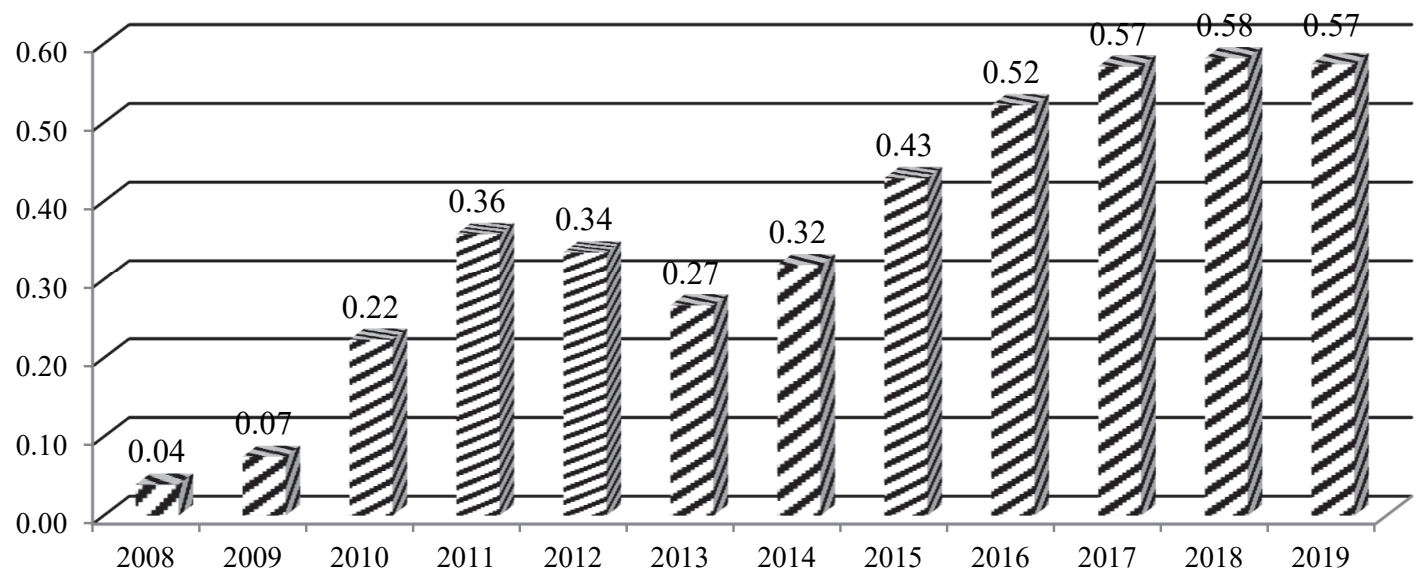

Fig. 1. Dynamics of the integrated indicator change of the information security level of Ukraine during 2008-2019

Source: own research

Creation of new facilities for high technology production, introduction of innovations of higher technology mode in industry, boosting of innovative activity in basic economy sectors, establishment of export-oriented technology intensive domestic production, creation and expansion of the activity volumes of integrated trade-production and scientific-technological systems are of priority importance in the context of strengthening of Ukrainian information security and its competitiveness on the grounds of technological modernization in modern conditions.

\section{Conclusion}

Informatization is an organizational socio-economic, scientific and technical process of creating optimal conditions for the comprehensive satisfaction of information needs and the realization of the rights of citizens, public authorities and government on the basis of the formation and use of information resources and the use of information systems, networks, resources, information technologies using computing and communication technology. The taxonomic analysis of the information security state in Ukraine as a system has shown that in order to ensure its development, it is advisable to systematically conduct such an assessment. A decrease in the taxonomy coefficient or even its certain stabilization when it differs from the ideal value is an impetus for the implementation of measures to increase the efficiency of the information security measures implementation and improve the mechanism for managing it. The interpretation of this indicator is as follows: it takes a high value at large values of stimulants and a low value - at low values of stimulants. The taxonomic indicator constructed in this way synthetically characterizes changes in the value of the characteristics of the researched groups. More importantly, its advantage is that now we are dealing with one synthetic trait, it shows the direction and scale of changes in the processes described by the set of initial data. Summing up, it can be noted that the taxonomy coefficient of information security of Ukraine during 2008-2019 was unstable during the analyzed periods. The closer the indicator is to one, the better the information security development.

\section{References}

Andrusiv, U., Kinash, I., Cherchata, A., Polyanska, A., Dzoba, O., Tarasova, T., \& Lysak, H. (2020). Experience and prospects of innovation development venture capital financing. Management Science Letters, 10(4), 781-788. https://doi.org/10.5267/j.msl.2019.10.019

Avramenko, A. B., \& Gaseskiy, V. K. (2012). Information security in Ukraine as a component of national security. Coll. of sciences WADU, 18, 9-18.

Day, A.C.L. (1955). The taxonomic approach to the study of economic policies. The American Economic Review, 45, 64-78.

Edsand, H.-E. (2019). Technological innovation system and the wider context: A framework for developing countries. Technology in Society, 58, 101-115. doi.org/10.1016/j.techsoc.2019.101150

European Commission. (2019). Europe 2020. A strategy for smart sustainable and inclusive growth. Retrieved November, 26, 2020 from: https://www.//ec.europa.eu/europe2020/index en.htm 
Hellwig Z. (1981). Wielowymiarowa analiza porównawcza i jej zastosowanie w badaniach wielocechowych obiektów gospodarczych [w:] Metody i modele ekonomiczno-matematyczne w doskonaleniu zarządzania gospodarką socjalistyczną, pod red. W. Welfe, PWE, Warszawa.

Ilyash, O., Dzhadan, I., \& Ostasz, G. (2018). The influence of the industry's innovation activities indices on the industrial products' revenue of Ukraine. Economics and Sociology, 11(4), 317-331. doi.org/10.14254/2071-789X.2018/11-4/21

Ivanova, A. S., Holionko, N. G., Tverdushka, T. B., Olejarz, T., \& Yakymchuk, A. Y. (2019). The Strategic Management in Terms of an Enterprise's Technological Development. Journal of Competitiveness, 11(4), 40-56. https://doi.org/10.7441/joc.2019.04.03

Kozhushko, O. (2014). "Taxonomy method during the intellectual capital protection evaluation in the industrial enterprises". Retrieved November, 22, 2020 from: http://www.library.tane.edu.ua/images/nauk_vydannya/5SIjDC.pdf

Litvinenko, O. V. (2003) Influences and operations. Theoretical and analytical essays: monograph. K.: NISD.

Popadynets, N., \& Maksymiv, Y. (2016). Development of the market of solid biofuel in Ukraine under current conditions. Economic Annals-XXI, 159(5-6), 93-96.

Matthews, J. G., \& Fink, C.D. (2001). Numerical methods. Using MATLAB. - 3rd edition. - M., SPb.: Williams.

Pavlova, O., Pavlov. K., Novosad, O., Irtyshcheva, I., Popadynets, N., Hryhoruk, I., Gelich, N., Suriak, A., Makara, O., Zhuk, O., Boiko, Y., \& Kramarenko I. (2021) Strategic Priorities for Socio-economic Development of Ukraine in Comparison with the Republic of Poland. In: Karwowski W., Ahram T., Etinger D., Tanković N., Taiar R. (eds) Human Systems Engineering and Design III. IHSED 2020. Advances in Intelligent Systems and Computing, 1269. Springer, Cham. https://doi.org/10.1007/978-3-030-58282-1_49

Petrik, V. M, \& Galamba, M. V. (2006). Information Security of Ukraine: Concept, Essence and Threats. Law Journal, 11, 49-52.

Pliuta, V. (1980). Comparative multidimensional analysis in the economic researches: methods of the taxonomy and the factor analysis., Moscow: Statistika.

Pryshchepa O. V., Kardash O. L., Yakymchuk A. Y., Shvec M.D., Pavlov K. V., Pavlova O.M., Irtyshcheva I., Popadynetsd N., Boiko Y., Kramarenko I. (2020). Optimization of Multi-Channel Queueing Systems With a Single Retrial Attempt: Economic Approach. Decision Science Letters, 9, 4. 559-564. 10.5267/j.ds1.2020.8.002

Riepina, I.M. (2011). Taxonomic analysis of the efficiency of formation and use of enterprise assets. Formu- market economy, $26,440-457$.

Shulga, V. I. (2015). Modern approaches to the interpretation of the concept of information security. Electronic scientific specialized edition "Effective economy", 4. Retrieved November, 22, 2020 from: http://www.economy.nayka.com.ua/?op $=1 \& z=5514$

Stehnei, M., Irtyshcheva, I., Popadynets, N., Bogatyrev, K., Boiko, Ye., Kramarenko, I., Senkevicha, O., Hryshyna, N., Kozak, I., \& Ishchenko, O. (2021). The effect of digital technology development on economic growth. International Journal of Data and Network Science, 5(1), 25-36. doi: 10.5267/j.ijdns.2020.11.006

Stroyko, T., Irtyshcheva, I., \& Stehney, M. (2013) Public regulation of integration systems development in agri-food sphere of Ukraine under globalization. Actual problems of economics, 3,125-134.

The official site of State Statistics Service of Ukraine (2020), Retrieved November, 24, 2020 from: https://ukrstat.org/en/operativ/oper new e.html

Vasyltsiv, T., Irtyshcheva, I., Lupak, R., Popadynets, N., Shyshkova, Y., Boiko, Y., \& Ishchenko, O. (2020). Economy’s Innovative Technological Competitiveness: Decomposition, Methodics of Analysis and Priorities of Public Policy. Management Science Letters, 10(13), 3173-3182. doi: 10.5267/j.msl.2020.5.004

Veche (2015). Information security of society. Retrieved November, 19, 2020 from: http://veche.kiev.ua/journal/4685

Was, A., Sulewski, P., Krupin, V., Popadynets, N., Malak-Rawlikowska, A., Szymanska, M., Skorokhod, I., \& Wysoki'nski, M. (2020). The Potential of Agricultural Biogas Production in Ukraine - Impact on GHG Emissions and Energy Production. Energies, 13 (5755), 1-20. doi:10.3390/en13215755

Wisz, G., Nykyruy, L., Yakubiv, V., Hryhoruk, I., Yavorsky, R. (2018). Impact of Advanced Research on Development of Renewable Energy Policy: Case of Ukraine. International Journal of Renewable Energy Research, 8, 4, Retrieved from https://www.ijrer.org/ijrer/index.php/ijrer/article/view/8688

Yakubiv, V. (2015). Accounting and analytical methods of diagnostics improvement for enterprises' organizational development. Economic Annals-XXI, 3-4(1), 68-71.

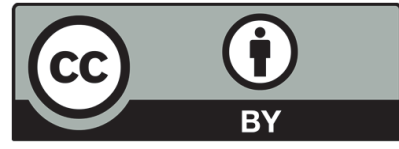

(C) 2021 by the authors; licensee Growing Science, Canada. This is an open access article distributed under the terms and conditions of the Creative Commons Attribution (CC-BY) license (http://creativecommons.org/licenses/by/4.0/). 